\title{
INTERNATIONAL COMPETITIVENESS IN TURKISH TEXTILE AND CLOTHING SECTOR
}

\author{
Assoc. Prof. Murat Ozan BAŞKOL \\ Bursa Uludağ University, FEAS, Bursa, Turkey, (obaskol@uludag.edu.tr)
}

\begin{abstract}
This study aims to examine the competitiveness of the Turkish textile and clothing sector. The competitiveness of the Turkish textile and clothing sector was examined, using Balassa's RCA Index and Vollrath's measures of competitiveness. This study on the competitiveness of the Turkish textile and clothing sector finds that the Turkish textile and clothing sector is competitive in world markets. However, in recent years, it was seen that there had been a considerable decline in the competitiveness of clothing industry. In order to maintain the competitiveness of the Turkish textile and clothing sector it is necessary to focus on the production of high value-added goods and the policies should be developed to strengthen the sector's research and development capacity.
\end{abstract}

Keywords: International Competitiveness, Textile and Clothing Sector, Revealed Comparative Advantage.

\section{TÜRK TEKSTIL VE HAZIR GIYIM SEKTÖRÜNDE ULUSLARARASI REKABET}

\begin{abstract}
ÖZET
Bu çallşmanın amacı, Türk tekstil ve hazır giyim sektörünün rekabet gücünü analiz. etmektir. Türk tekstil ve hazır giyim sektörünün rekabet gücü Balassa (RCA endeksi) ve Vollrath'ın geliştirdiğ i endeksler yardımıyla analiz edilmiş ve sektörün dünya piyasasında belirli bir rekabet gücüne ulaştı̆̆g görülmüşü̈r. Fakat özellikle son yıllarda hazır giyim sektörünün rekabet gücündeki gerileme dikkat çekicidir. Türk tekstil ve hazır giyim sektörünün rekabet gücünü sürdürebilmesi için, katma değeri yüksek ürünlerin üretimine odaklanmast ve sektörün araştırma geliştirme kapasitesini güçlendirici politikaların geliştirilmesi gerekmektedir.
\end{abstract}

Anahtar Kelimeler: Uluslararası Rekabet Gücü, Tekstil ve Hazır Giyim Sektörü, Açıklanmış Karşılaştırmalı Üstünlükler. 


\section{Introduction}

The textile and clothing industry has major importance in the Turkish economy. Turkish textile and clothing sector accounts for 14.4 percent of production, 16.2 percent of value added and 26.2 percent of employment in manufacturing and 18,0 percent of total exports.

Turkey is the 6th largest textile and clothing exporter in the world. Turkey is one of the three countries that give the most trade surplus in the sector. The Turkish textile and clothing sector, which attracts attention with its net exporter structure, is also one of the leading sectors of Turkey's exports.

The aim of this paper is to examine Turkey's international competitiveness of textile and clothing industries as a whole and within the sub-sectors of these industries. The rest of this paper is structured as follows. An overwiew of the Turkish textile and clothing industry is presented in Section 2. In Section 3, the study briefly summarizes the literature on the competitiveness of the Turkish textile and clothing sector. The methodology, data and empirical results of the study is discussed in Section 4. The final section summarizes the main results.

\section{An Overview of the Turkish Textile and Clothing Industry}

Textile and clothing sector is one of the leading sectors in Turkish economy in terms of industrial production and employment. According to data from 2015, there were 72,830 companies in the industry employing nearly 900.000 people and generating a turnover of 1,125 billion TL. The sector accounts for 14.4 percent of production, 16.2 percent of value added and 26.2 percent of employment in manufacturing in Turkey (Table 1).

Table 1: Textile and Clothing Sector: Basic Indicators, 2015 (billion TL)

\begin{tabular}{lccccc}
\hline & $\begin{array}{c}\text { Production } \\
\text { value }\end{array}$ & $\begin{array}{c}\text { Value added } \\
\text { (at factor } \\
\text { costs) }\end{array}$ & Turnover & $\begin{array}{c}\text { Number of } \\
\text { enterprises }\end{array}$ & $\begin{array}{c}\text { Number } \\
\text { of persons } \\
\text { employed }\end{array}$ \\
\hline Textile & 89,5 & 22,4 & 94,7 & 21.413 & 416.099 \\
\hline Clothing & 63,2 & 14,5 & 66,4 & 51.417 & 480.912 \\
\hline Textile and Clothing & 152,7 & 36,9 & 161,1 & 72.830 & 897.011 \\
\hline Manufacturing Industry & $1.062,8$ & 227,4 & $1.125,3$ & 335.311 & 3.426 .368 \\
\hline $\begin{array}{l}\text { Share in Manufacturing } \\
\text { Industry (\%) }\end{array}$ & $\% 14,4$ & $\% 16.2$ & $\% 14,3$ & $\% 21,7$ & $\% 26,2$ \\
\hline
\end{tabular}

Source: Turkish Statistical Institute (2016), Annual Industry and Service Statistics, http://tuik.gov.tr/PreHaberBultenleri. do? id=21528, Accessed: 29.12.2016

In 2015, the textile and clothing industry's exports represented 4.2 percent of the world's total exports. China is the leading textile and clothing exporter with a 41.3 percent share in world exports of textiles and clothing. China is followed by India 35.3 billion US \$ (5.1\%), Italy 32.9 billion US \$ (4.8\%), Germany 29.9 billion US \$ (4.3\%) and Hong Kong 27.5 billion US \$ (4.0\%.). Turkey is the sixth largest textile and clothing exporter of the world with a share of $3.8 \%$ in 2015 (Table 2). 
Table 2: Leading Exporters of Textiles and Clothing, 2015

\begin{tabular}{lccccccc}
\hline & \multicolumn{2}{c}{ Textiles } & \multicolumn{2}{c}{ Clothing } & \multicolumn{3}{c}{ Textiles and Clothing } \\
\hline & Billion $\$$ & \% & Billion $\$$ & \% & Billion \$ & \% & Rank \\
\hline China & 108.9 & 38,8 & 174.7 & 43.0 & 283.6 & 41.3 & 1 \\
\hline India & 17.2 & 6,1 & 18.1 & 4.5 & 35.3 & 5.1 & 2 \\
\hline Italy & 11.7 & 4,2 & 21.2 & 5.2 & 32.9 & 4.8 & 3 \\
\hline Germany & 12.6 & 4,5 & 17.3 & 4.3 & 29.9 & 4.3 & 4 \\
\hline Hong Kong & 9.1 & 3,2 & 18.4 & 4.5 & 27.5 & 4.0 & 5 \\
\hline Turkey & 10.9 & 3,9 & 15.1 & 3.7 & 26.0 & 3,8 & 6 \\
\hline Total & 281.0 & & 406.3 & & 687.3 & & \\
\hline
\end{tabular}

Source: UN Comtrade Database (2016), Trade Statistics, http://comtrade.un.org/data/, Accessed: 19.10.2016

While the export value of the Turkish textile and clothing sector was 4,1 billion US $\$$ in 1989 , it has reached to 26,1 billion US $\$$ by the end of 2015 . In other words, the total textile and clothing exports of Turkey has increased six-fold within the last 26 years. The share of the sector in Turkey's total exports was 18,0 percent in 2015 in value with around 26 billion US \$. Turkey was one of the three countries which gave a trade surplus in the sector. China's textiles sector's trade surplus was 257.8 billion US \$, followed by India with 30.8 billion US \$ and Turkey with around 17 billion US \$ in 2015.

Table 3: Turkey's Textile and Clothing Exports, 1989-2015

\begin{tabular}{|c|c|c|c|c|c|c|}
\hline & \multicolumn{3}{|c|}{ Textile } & \multicolumn{3}{|c|}{ Clothing } \\
\hline & $\begin{array}{c}\text { Export } \\
(1.000 \$)\end{array}$ & $\begin{array}{l}\text { Import } \\
(1.000 \$)\end{array}$ & $\begin{array}{c}\text { Net Export } \\
(1.000 \$)\end{array}$ & $\begin{array}{c}\text { Export } \\
(1.000 \$)\end{array}$ & $\begin{array}{l}\text { Import } \\
(1.000 \$)\end{array}$ & $\begin{array}{c}\text { Net Export } \\
(1.000 \$)\end{array}$ \\
\hline 1989 & 1.330 .972 & 293.170 & 1.037 .802 & 2.740 .787 & 5.550 & 2.735 .237 \\
\hline 1990 & 1.440 .449 & 567.240 & 873.209 & 3.330 .682 & 16.124 & 3.314 .558 \\
\hline 1991 & 1.429 .076 & 537.348 & 891.728 & 3.478 .251 & 26.121 & 3.452 .130 \\
\hline 1992 & 1.618 .685 & 706.856 & 911.829 & 4.179 .163 & 29.470 & 4.149 .693 \\
\hline 1993 & 1.592 .262 & 1.017 .975 & 574.287 & 4.339 .448 & 45.614 & 4.293 .834 \\
\hline 1994 & 2.194 .370 & 1.110 .396 & 1.083 .974 & 4.581 .636 & 35.179 & 4.546 .457 \\
\hline 1995 & 2.526 .550 & 1.810 .635 & 715.915 & 6.118 .750 & 48.954 & 6.069 .796 \\
\hline 1996 & 2.722 .354 & 1.932 .836 & 789.518 & 6.067 .023 & 152.208 & 5.914 .815 \\
\hline 1997 & 3.352 .039 & 2.323 .914 & 1.028 .125 & 6.697 .152 & 232.704 & 6.464 .448 \\
\hline 1998 & 3.548 .950 & 2.316 .984 & 1.231 .966 & 7.057 .654 & 242.723 & 6.814 .931 \\
\hline 1999 & 3.477 .794 & 1.906 .871 & 1.570 .923 & 6.515 .961 & 208.112 & 6.307 .849 \\
\hline 2000 & 3.672 .213 & 2.123 .801 & 1.548 .412 & 6.533 .095 & 263.760 & 6.269 .335 \\
\hline 2001 & 3.942 .661 & 1.920 .722 & 2.021 .939 & 6.661 .072 & 238.876 & 6.422 .196 \\
\hline
\end{tabular}


Table 3 continued

\begin{tabular}{lllllll}
\hline 2002 & 4.244 .056 & 2.839 .047 & 1.405 .009 & 8.056 .608 & 283.287 & 7.773 .321 \\
\hline 2003 & 5.261 .666 & 3.440 .633 & 1.821 .033 & 9.961 .747 & 422.444 & 9.539 .303 \\
\hline 2004 & 6.428 .477 & 4.169 .512 & 2.258 .965 & 11.193 .385 & 651.348 & 10.542 .037 \\
\hline 2005 & 7.075 .507 & 4.440 .514 & 2.634 .993 & 11.833 .105 & 787.840 & 11.045 .265 \\
\hline 2006 & 7.584 .693 & 4.686 .040 & 2.898 .653 & 12.051 .921 & 1.097 .719 & 10.954 .202 \\
\hline 2007 & 8.942 .139 & 6.008 .750 & 2.933 .389 & 13.886 .333 & 1.566 .561 & 12.319 .772 \\
\hline 2008 & 9.399 .326 & 5.646 .119 & 3.753 .207 & 13.590 .731 & 2.216 .248 & 11.374 .483 \\
\hline 2009 & 7.723 .826 & 4.718 .389 & 3.005 .437 & 11.555 .926 & 2.147 .280 & 9.408 .646 \\
\hline 2010 & 8.963 .669 & 6.539 .558 & 2.424 .111 & 12.760 .244 & 2.835 .229 & 9.925 .015 \\
\hline 2011 & 10.772 .416 & 7.557 .232 & 3.215 .184 & 13.947 .693 & 3.271 .716 & 10.675 .977 \\
\hline 2012 & 11.054 .288 & 6.440 .721 & 4.613 .567 & 14.289 .647 & 2.677 .184 & 11.612 .463 \\
\hline 2013 & 12.148 .882 & 6.789 .494 & 5.359 .388 & 15.393 .251 & 3.139 .926 & 12.253 .325 \\
\hline 2014 & 12.516 .098 & 7.117 .244 & 5.398 .854 & 16.667 .624 & 3.228 .715 & 13.438 .909 \\
\hline
\end{tabular}

Source: UN Comtrade Database (2016), Trade Statistics, http://comtrade.un.org/data/, Accessed: 19.10.2016

Germany (18\%), the United Kingdom (13,9\%), Spain (10,8\%), France $(5,0 \%)$ and the Netherlands $(4,7 \%)$ are the most important markets for Turkey's clothing exports. Clothing exports to these countries were 7,9 billion US \$, which constituted 52, 4 percent of Turkey's clothing exports. Germany is the largest market for Turkish textiles with a market share of 8.7 percent in 2015 . Italy (7.2\%) is the second largest market for Turkish clothing sector after Germany. These countries were followed by the United States $(7,1 \%)$, the Russian Federation $(4,6 \%)$ and the United Kingdom $(4,5 \%)$.

Textile and clothing sector is also one of the most important net exporter sector in Turkey. 70 percent of the textile and clothing sector's trade surplus stems from the clothing sector. In the period of 1989-2015, textile and clothing sector contributed 280.4 billion US \$ to the Turkish economy. Trade surplus in the sector has contributed 98 billion US $\$$ to the net international reserves of Turkey's economy during the period 2004-2014. (Türkiye Tekstil ve Sanayi İşverenleri Sendikası, 2015:30)

\section{Literature Review}

Some studies in the literature on the competitiveness of the Turkish textile and clothing sector can be summarized as follows.

Turkey's comparative advantage and international competitiveness of textiles and clothing industries, using Balassa's revealed comparative advantage (RCA) index and Vollrath's measures of competitiveness, has been examined by Aynagöz Çakmak (2005). She states that, in terms of RCA index, Turkey has a strong comparative advantage in textiles and clothing both 
as an aggregate commodity group and in the sub-sectors of these industries. She pointed out that in aggregate commodity groups of textiles and clothing, in terms of the Vollrath's indices, Turkey is less competitive in the world market compared to RCA index. The study finds that clothing sector is more competitive than textiles in the world markets, but the competitiveness of almost all sub-sectors falls recently. The study also suggests that technological improvements are essential for the continued competitiveness of Turkish textile and apparel industries in the EU and world markets.

Kök \& Çoban (2005), employing Balassa RCA index, compare the competitiveness of textile industries of Turkey and the EU. The study finds that in terms of the product groups within both SITC 2 and 3-digit classifications, the competitiveness of the Turkish textile industry is high, although there has been a considerable decline in the competitiveness of almost all product groups. The empirical results reveal that in order not to lose the competitive advantage in the Turkish textile industry, it is essential to focus on the production of high value-added goods and to develop a new trademark policy with an eye towards creating brand names on the basis of product differentiation and in response to regional market characteristics. (Çoban \& Kök, 2005:80)

Kösekahyaoğlu \& Özdamar (2009) indicate that Turkey has a comparative advantage with regard to the EU especially in textile and clothing compared to chemicals and related products and machinery and transport equipment.

Karaalp \& Y1lmaz (2012) examined comparative advantage and competitiveness of the Turkish textile and clothing industries by using Balassa's RCA index and Vollrath's indices of competitive advantage for the period of 1988-2008 in the enlarged EU market. Karaalp and Yilmaz state that Turkey has a strong comparative advantage and competitiveness in textile and clothing in the EU market. The study finds that all competitiveness indices for the period 20052008 showed an increasing trend for the textile industry and a decreasing trend for clothing and the decrease in the competitiveness of clothing was observed more intensively in the enlarged EU market compared to that of EU 12.

Erkan (2013) examined the international competitiveness in Turkey's export of textile and apparel sector by using Balassa Index, Vollrath Index and Export-Import Rate Index for the period of 1993-2009. Erkan pointed out that Turkey has a comparative advantage in the export of 43 out of 59 textile products and in the export of 34 out of 37 apparel products in the SITC 4-digit classification.

Karaalp \& Yilmaz (2013) analyze the comparative advantage of four countries in the world: Bangladesh, China, Germany and Turkey with respect to the US and the EU-15 textiles and clothing markets by employing Balassa's revealed comparative advantage index. Karaalp and Yilmaz found that Bangladesh, China and Turkey have a strong comparative advantage in both the textile and clothing markets of the world, the US and the EU-15, while Germany has no significant comparative advantage in any of these markets.

Gacaner Atış (2014) analyzed the competitiveness of the Turkish textile and clothing sector vis-à-vis the EU, the US, the Middle East and the North Africa markets by using Balassa's RCA index, Vollrath's revealed competitiveness and comparative export performance indices 
for the period 1995-2012. The results revealed that the importance of Turkey's textile and clothing industry remains strong, but that it gradually decreased in certain product groups in its major trading markets.

\section{The Methodology, Data and Empirical Results}

The methodology, data and empirical results of the study discussed in this section.

\subsection{Methodology}

The revealed comparative advantage is an index used in international economics for measuring the international competitiveness of a sector. Although the index for the first time was used by Liesner (1958) to measure the revealed comparative advantage of the UK with the Common Market, a comprehensive measure of revealed comparative advantage was later developed by Balassa (1965). Balassa proposes that comparative advantage may be "revealed" by observed trade patterns that are assumed to reflect relative costs and differences in non-price factors (Vollrath,1991:266, Havrina \& Gunawardana, 2003:108; Y1lmaz, 2010:231).

Balassa's RCA index written as follows:

$$
R C A_{i j}=\frac{X_{i j} / X_{i t}}{X_{w j} / X_{w t}}
$$

$\mathrm{RCA}_{\mathrm{ij}}$ is the revealed comparative advantage index for industry $\mathrm{j}$ of country $\mathrm{i}, \mathrm{X}_{\mathrm{ij}}$ and $\mathrm{X}_{\mathrm{wj}}$ are the values of country i's exports of product $\mathrm{j}$ and world exports of product $\mathrm{j}$ and $\mathrm{X}_{\mathrm{it}}$ and $\mathrm{X}_{\mathrm{wt}}$ refer to the country's total exports and world total exports. The RCA index of country $\mathrm{i}$ for product $\mathrm{j}$ is measured by the product's share in the country's exports in relation to its share in world trade.

If the value of the RCA index $>1$, it is interpreted that the country has a revealed comparative advantage. In other words, the product's share in the country's total exports is greater than its share in the world. If the value of the RCA index $<1$ the country is said to have a comparative disadvantage in the product.

Vollrath (1991) suggested three alternative ways of measuring the RCA of a country (i) the relative export advantage (RXA) (ii) the relative trade advantage (RTA) and (iii) the revealed competitiveness $(\mathrm{RC})$.

Vollrath's RXA index written as follows:

$$
R X A_{i j}=\frac{X_{i j} / X_{i t}}{X_{w j} / X_{w t}}
$$

$$
R X A=\ln R X A_{i j}
$$


RXA $_{i j}$ is the relative export advantage index for product $\mathrm{j}$ of country $\mathrm{i}, \mathrm{X}_{\mathrm{ij}} ; \mathrm{x}_{\mathrm{ij}}$ and $\mathrm{x}_{\mathrm{wj}}$ are the values of country $i$ 's exports of product $j$ and world exports of product $j$ and $X_{i t}$ and $X_{w t}$ refer to country's total exports and world total exports except exports of product $\mathrm{j}$.

The relative trade advantage (RTA) is calculated as the difference between relative export advantage (RXA) and relative import advantage (RMA).

$$
\begin{aligned}
& R T A_{i j}=R X A_{i j}-R M A_{i j} \\
& R T A_{i j}=\frac{X_{i j} / X_{i t}}{X_{w j} / X_{w t}}-\frac{M_{i j} / M_{i t}}{M_{w j} / M_{w t}}
\end{aligned}
$$

RTA $_{i j}$ is the relative trade advantage index for $\mathrm{j}$ of country $\mathrm{i}, \mathrm{M}_{\mathrm{ij}}$ and $\mathrm{M}_{\mathrm{wj}}$ are the values of country i's imports of product $\mathrm{j}$ and world imports of product $\mathrm{j}$ and $\mathrm{M}_{\mathrm{it}}$ and $\mathrm{M}_{\mathrm{wt}}$ refer to country's total exports and world total exports except imports of product $\mathrm{j}$.

Vollrath's third measure is revealed competitiveness (RC), defined as

$$
R C_{i j}=\ln \left(R X A_{i j}\right)-\ln \left(R M A_{i j}\right)
$$

$\mathrm{RC}_{\mathrm{ij}}$ is the revealed competitiveness for product $\mathrm{j}$ of country $\mathrm{i}$.

According to Vollrath, a positive RXA, RTA ve RC reveals a comparative advantage while a negative value reveals a comparative disadvantage (Vollrath, 1991:276)

\subsection{Data}

The empirical analysis was based on trade data of the sector (SITC Rev.3 2 and 3 digit level of aggregation) which is obtained from UNCOMTRADE database for the period 1989 to 2015. Textile and clothing sector was classified as:

SITC 65 Textile yarn, fabrics, made up articles and related products

SITC 651 Textile yarn

SITC 652 Cotton fabrics, woven

SITC 653 Fabrics, woven, of man-made textile materials

SITC 654 Other textile fabrics, woven

SITC 655 Knitted or crocheted fabrics

SITC 656 Tulles, lace, embroidery, ribbons, trimmings and other small wares

SITC 657 Special yarns, special textile fabrics and related products 
SITC 658 Made-up articles, wholly or chiefly of textile materials

SITC 659 Floor coverings (including linoleum and similar products), tapestries and tablecloths, etc.

SITC 84 Articles of apparel and clothing accessories

SITC 841 Men's or boys' apparel of textile fabrics, not knitted or crocheted

SITC 842 Women's or girls' apparel of textile fabrics, not knitted or crocheted

SITC 843 Men's or boys' apparel, knitted or crocheted

SITC 844 Women's or girls' apparel, knitted or crocheted

SITC 845 Articles of apparel and clothing accessories for babies, articles of apparel of textile fabrics

SITC-846 Clothing accessories, of textile fabrics

SITC-848 Articles of apparel and clothing accessories of other than textile fabrics; headgear of all materials

\subsection{Empirical Results}

The Balassa's RCA index of Turkey's textiles and clothing sector at the SITC 2-digit level is given in Table 4. Turkey has a comparative advantage in both textile and clothing. However, a decrease in the competitiveness of Turkish clothing sector is remarkable. The study finds that clothing sector was more competitive than textiles in the world markets until 2007, but that after 2008 the textile sector became more competitive.

Table 4: The Balassa RCA Index for Turkish Textile and Clothing Sector,1989-2015

\begin{tabular}{lcc}
\hline & $\begin{array}{c}\text { SITC 65: Textile yarn, fabrics, } \\
\text { made up articles and related products }\end{array}$ & $\begin{array}{c}\text { SITC 84 :Articles of apparel and } \\
\text { clothing accessories }\end{array}$ \\
\hline 1989 & 3,9 & 9,2 \\
\hline 1990 & 3,6 & 9,6 \\
\hline 1991 & 3,4 & 9,2 \\
\hline 1992 & 3,2 & 7,6 \\
\hline 1993 & 3,1 & 7,6 \\
\hline 1994 & 3,7 & 7,2 \\
\hline 1995 & 3,6 & 8,8 \\
\hline 1996 & 3,8 & 8,2 \\
\hline 1997 & 4,1 & 7,4 \\
\hline
\end{tabular}


Table 4 continued

\begin{tabular}{lll}
\hline 1998 & 4,4 & 7,6 \\
\hline 1999 & 4,6 & 7,4 \\
\hline 2000 & 5,1 & 7,5 \\
\hline 2001 & 4,9 & 6,6 \\
\hline 2002 & 4,6 & 6,9 \\
\hline 2003 & 4,5 & 6,6 \\
\hline 2004 & 4,5 & 6,0 \\
\hline 2005 & 4,6 & 5,7 \\
\hline 2007 & 4,6 & 5,2 \\
\hline 2008 & 4,6 & 4,9 \\
\hline 2009 & 4,4 & 4,3 \\
\hline 2010 & 4,3 & 4,2 \\
\hline 2011 & 4,6 & 4,6 \\
\hline 2012 & 4,8 & 4,3 \\
\hline 2013 & 4,5 & 4,1 \\
\hline 2014 & 4,8 & 4,2 \\
\hline 2015 & 4,6 & 4,2 \\
\hline
\end{tabular}

Source: Calculations based on UNCOMTRADE database

The Balassa's RCA index of the Turkish textile sector at the SITC 3-digit level is given in Table 5. SITC 659 floor coverings (including linoleum and similar products), tapestries and tablecloths, SITC 655 knitted or crocheted fabrics and SITC 652 cotton fabrics, woven sectors are the most competitive sub-sectors of the Turkish textile industry. The competitiveness of the sectors (SITC 652 cotton fabrics, woven, SITC 653 fabrics, woven, of man-made textile materials, SITC 654 other textile fabrics, woven, SITC 655 knitted or crocheted fabrics, SITC 656 tulles, lace, embroidery, ribbons, trimmings and other small wares, and SITC 659 floor coverings (including linoleum and similar products), tapestries and tablecloths) has increased during the period of 1989-2015. However, the competitiveness of SITC 651 Textile yarn, SITC 657 special yarns, special textile fabrics and related products and SITC 658 made-up articles, wholly or chiefly of textile materials sub-sectors has declined. 
Table 5: The Balassa RCA Index for Turkish Textile Sector, 1989-2015

\begin{tabular}{|c|c|c|c|c|c|c|c|c|c|}
\hline & 651 & 652 & 653 & 654 & 655 & 656 & 657 & 658 & 659 \\
\hline 1989 & 6,1 & 3,7 & 1,7 & 0,7 & 2,6 & 1,4 & 2,1 & 9,4 & 6,6 \\
\hline 1990 & 5,5 & 3,6 & 1,5 & 0,5 & 2,2 & 1,0 & 1,9 & 9,2 & 6,6 \\
\hline 1991 & 5,1 & 3,3 & 1,3 & 0,5 & 2,5 & 1,3 & 1,3 & 10,0 & 6,0 \\
\hline 1992 & 4,2 & 2,8 & 1,7 & 0,7 & 2,0 & 1,4 & 1,3 & 8,1 & 7,9 \\
\hline 1993 & 3,6 & 2,6 & 2,1 & 0,9 & 1,7 & 2,0 & 1,3 & 7,2 & 9,2 \\
\hline 1994 & 5,1 & 4,3 & 2,4 & 1,0 & 3,0 & 2,5 & 1,0 & 7,9 & 7,2 \\
\hline 1995 & 3,5 & 3,8 & 3,5 & 1,4 & 1,6 & 2,9 & 1,3 & 9,1 & 6,6 \\
\hline 1996 & 3,5 & 3,9 & 3,1 & 1,8 & 2,2 & 3,5 & 1,6 & 9,9 & 7,9 \\
\hline 1997 & 3,8 & 3,9 & 3,4 & 1,7 & 2,6 & 3,8 & 1,9 & 11,1 & 6,7 \\
\hline 1998 & 4,3 & 4,0 & 3,8 & 1,7 & 2,6 & 4,0 & 1,5 & 11,9 & 7,4 \\
\hline 1999 & 5,1 & 3,6 & 3,9 & 2,2 & 3,2 & 5,5 & 1,4 & 12,0 & 6,2 \\
\hline 2000 & 5,3 & 4,3 & 4,2 & 2,5 & 3,1 & 6,7 & 1,6 & 13,3 & 7,7 \\
\hline 2001 & 5,1 & 4,6 & 4,0 & 1,9 & 3,1 & 7,8 & 1,6 & 11,6 & 6,3 \\
\hline 2002 & 3,8 & 4,3 & 4,3 & 1,9 & 3,0 & 7,3 & 1,7 & 11,4 & 6,1 \\
\hline 2003 & 3,5 & 3,9 & 4,4 & 1,9 & 3,1 & 6,9 & 1,6 & 10,8 & 6,3 \\
\hline 2004 & 3,6 & 4,1 & 4,3 & 1,7 & 3,3 & 7,2 & 1,6 & 9,7 & 7,0 \\
\hline 2005 & 3,5 & 4,2 & 4,7 & 1,9 & 4,0 & 6,9 & 1,6 & 8,6 & 8,0 \\
\hline 2006 & 3,7 & 4,1 & 5,1 & 1,8 & 4,8 & 5,6 & 1,7 & 7,7 & 8,3 \\
\hline 2007 & 3,3 & 4,9 & 5,0 & 2,0 & 5,3 & 5,3 & 1,6 & 7,1 & 9,4 \\
\hline 2008 & 3,2 & 4,5 & 5,0 & 2,0 & 5,4 & 4,7 & 1,5 & 6,0 & 9,9 \\
\hline 2009 & 3,4 & 4,6 & 4,8 & 1,8 & 5,4 & 4,0 & 1,5 & 5,1 & 11,0 \\
\hline 2010 & 3,5 & 4,7 & 4,9 & 1,9 & 6,4 & 4,1 & 1,7 & 5,4 & 11,9 \\
\hline 2011 & 3,9 & 4,7 & 4,7 & 1,9 & 6,4 & 4,3 & 1,9 & 5,5 & 13,6 \\
\hline 2012 & 3,7 & 4,4 & 4,4 & 1,8 & 6,1 & 4,3 & 1,8 & 4,5 & 16,1 \\
\hline 2013 & 3,8 & 4,7 & 4,8 & 1,8 & 6,3 & 4,3 & 2,0 & 4,8 & 16,8 \\
\hline 2014 & 3,8 & 4,6 & 4,5 & 1,6 & 5,8 & 4,0 & 2,0 & 4,4 & 16,8 \\
\hline 2015 & 3,9 & 4,1 & 4,1 & 1,4 & 4,8 & 3,6 & 1,9 & 3,8 & 14,8 \\
\hline
\end{tabular}

Source: Calculations based on UNCOMTRADE database

The Balassa's RCA index of the Turkish clothing sector at the SITC 3-digit level is given in Table 6. The most competitive sub-sectors of clothing industry are SITC 844 Women's or girls' apparel, knitted or crocheted, SITC 845 Articles of apparel and clothing accessories for babies, articles of apparel of textile and SITC-846 Clothing accessories, of textile fabrics sectors. The competitiveness of almost all sub-sectors of clothing sector, except for SITC 846 
Clothing accessories, of textile fabrics, has declined. The decline in SITC 848 Articles of apparel and clothing accessories of other than textile fabrics; headgear of all materials sector is striking. The articles of apparel and clothing accessories of other than textile fabrics; headgear of all materials sector, which is the most competitive sector in 1989, has revealed comparative disadvantage in 2015.

Table 6: The Balassa RCA Index for Turkish Clothing Sector, 1989-2015

\begin{tabular}{|c|c|c|c|c|c|c|c|}
\hline & 841 & 842 & 843 & 844 & 845 & 846 & 848 \\
\hline 1989 & 6,5 & 8,4 & 3,5 & 13,7 & 9,9 & 3,1 & 17,0 \\
\hline 1990 & 6,3 & 8,3 & 4,8 & 16,3 & 9,9 & 3,3 & 20,2 \\
\hline 1991 & 5,1 & 7,7 & 4,7 & 18,6 & 10,2 & 4,2 & 17,0 \\
\hline 1992 & 3,9 & 5,4 & 4,7 & 20,9 & 8,5 & 3,8 & 11,5 \\
\hline 1993 & 4,0 & 5,6 & 5,2 & 20,9 & 8,6 & 4,4 & 10,3 \\
\hline 1994 & 3,9 & 5,4 & 6,3 & 16,4 & 8,7 & 5,0 & 9,4 \\
\hline 1995 & 5,4 & 7,3 & 8,3 & 19,9 & 10,1 & 5,7 & 8,5 \\
\hline 1996 & 4,8 & 7,1 & 8,7 & 17,0 & 10,1 & 5,7 & 6,2 \\
\hline 1997 & 4,7 & 6,7 & 6,1 & 13,4 & 8,7 & 5,1 & 6,5 \\
\hline 1998 & 4,7 & 6,8 & 6,8 & 13,7 & 9,4 & 5,1 & 5,8 \\
\hline 1999 & 4,9 & 7,3 & 6,1 & 11,6 & 8,9 & 5,2 & 5,5 \\
\hline 2000 & 4,9 & 7,9 & 5,3 & 11,7 & 8,9 & 5,7 & 5,9 \\
\hline 2001 & 4,5 & 7,4 & 4,6 & 9,3 & 7,4 & 5,6 & 5,2 \\
\hline 2002 & 4,9 & 7,7 & 5,0 & 9,5 & 7,8 & 6,0 & 4,9 \\
\hline 2003 & 4,8 & 6,9 & 3,9 & 9,2 & 7,8 & 6,4 & 3,9 \\
\hline 2004 & 4,8 & 6,5 & 3,3 & 7,5 & 7,0 & 6,5 & 3,0 \\
\hline 2005 & 4,8 & 6,1 & 3,2 & 6,9 & 6,6 & 6,2 & 2,5 \\
\hline 2006 & 4,3 & 5,6 & 3,1 & 6,4 & 5,8 & 6,0 & 2,7 \\
\hline 2007 & 4,3 & 5,4 & 2,9 & 5,8 & 5,2 & 5,8 & 2,5 \\
\hline 2008 & 3,9 & 4,5 & 3,0 & 5,4 & 4,4 & 4,8 & 2,2 \\
\hline 2009 & 3,7 & 4,2 & 3,0 & 5,3 & 4,3 & 5,5 & 1,9 \\
\hline 2010 & 4,2 & 4,7 & 2,7 & 5,8 & 4,9 & 5,6 & 2,0 \\
\hline 2011 & 3,8 & 4,6 & 2,5 & 5,2 & 4,7 & 5,2 & 1,9 \\
\hline 2012 & 4,0 & 4,7 & 2,5 & 4,1 & 4,7 & 4,5 & 1,7 \\
\hline 2013 & 4,0 & 4,8 & 2,8 & 4,0 & 4,9 & 5,0 & 1,7 \\
\hline 2014 & 3,8 & 4,4 & 3,1 & 4,4 & 4,8 & 5,0 & 1,4 \\
\hline 2015 & 4,0 & 4,2 & 3,2 & 4,6 & 4,4 & 4,4 & 0,9 \\
\hline
\end{tabular}


Vollrath's RXA, RTA and RC indices for Turkey's textiles and clothing sector at the SITC 2-digit level are given in Table 7. A positive values of Vollrath's RXA, RTA and RC indices also show that Turkey has a comparative advantage in textiles and clothing.

Table 7: The Vollrath's RXA,RTA and RC Indices for Turkish Textile and Clothing Sector, 1989- 2015

\begin{tabular}{ccccccc}
\hline & \multicolumn{2}{c}{$\begin{array}{c}\text { SITC 65: Textile yarn, fabrics, } \\
\text { made up articles and related products }\end{array}$} & \multicolumn{3}{c}{$\begin{array}{c}\text { SITC 84 Articles of apparel and } \\
\text { clothing accessories }\end{array}$} \\
\hline & In RXA & RTA & RC & In RXA & RTA & RC \\
\hline 1989 & 1,44 & 3,53 & 1,80 & 2,46 & 11,67 & 7,06 \\
\hline 1990 & 1,36 & 2,95 & 1,42 & 2,54 & 12,60 & 6,45 \\
\hline 1991 & 1,30 & 2,73 & 1,37 & 2,49 & 12,02 & 6,00 \\
\hline 1992 & 1,24 & 2,47 & 1,26 & 2,33 & 10,25 & 5,84 \\
\hline 1993 & 1,20 & 2,18 & 1,06 & 2,32 & 10,18 & 5,54 \\
\hline 1994 & 1,39 & 2,41 & 0,92 & 2,22 & 9,21 & 5,44 \\
\hline 1995 & 1,36 & 2,09 & 0,77 & 2,47 & 11,78 & 5,69 \\
\hline 1996 & 1,43 & 2,49 & 0,91 & 2,37 & 10,63 & 4,68 \\
\hline 1997 & 1,50 & 2,70 & 0,92 & 2,26 & 9,41 & 4,22 \\
\hline 1998 & 1,59 & 2,98 & 0,94 & 2,29 & 9,76 & 4,26 \\
\hline 1999 & 1,64 & 3,26 & 1,01 & 2,24 & 9,30 & 4,21 \\
\hline 2000 & 1,74 & 4,03 & 1,22 & 2,26 & 9,41 & 4,15 \\
\hline 2001 & 1,69 & 3,39 & 0,99 & 2,09 & 7,91 & 3,92 \\
\hline 2002 & 1,63 & 2,65 & 0,73 & 2,16 & 8,48 & 3,99 \\
\hline 2003 & 1,60 & 2,62 & 0,75 & 2,09 & 7,89 & 3,80 \\
\hline 2004 & 1,59 & 2,70 & 0,80 & 1,96 & 6,87 & 3,47 \\
\hline 2005 & 1,61 & 2,88 & 0,86 & 1,89 & 6,35 & 3,31 \\
\hline 2006 & 1,61 & 2,94 & 0,89 & 1,77 & 5,60 & 2,98 \\
\hline 2007 & 1,60 & 2,67 & 0,78 & 1,70 & 5,10 & 2,72 \\
\hline 2008 & 1,53 & 2,64 & 0,85 & 1,53 & 4,15 & 2,29 \\
\hline 2009 & 1,52 & 2,34 & 0,72 & 1,52 & 3,99 & 2,08 \\
\hline 2010 & 1,58 & 2,43 & 0,69 & 1,61 & 4,35 & 2,05 \\
\hline 2011 & 1,62 & 2,83 & 0,82 & 1,53 & 4,05 & 2,06 \\
\hline 2012 & 1,57 & 2,71 & 0,83 & 1,49 & 3,92 & 2,16 \\
\hline 2013 & 1,64 & 3,13 & 0,94 & 1,52 & 4,04 & 2,12 \\
\hline 2014 & 1,60 & 2,81 & 0,84 & 1,51 & 3,97 & 2,09 \\
\hline 2015 & 1,49 & 2,27 & 0,72 & 1,47 & 3,79 & 2,07 \\
\hline 5045 & & & & & & \\
\hline
\end{tabular}

Source: Calculations based on UNCOMTRADE database

In the study Vollrath's revealed trade advantage index is also calculated for Turkey's textiles and clothing sector at the SITC 3-digit level. The results are given in Table 8 and Table 9.

The negative values of the revealed trade advantage index in the SITC 651 textile yarn and SITC 654 other textile fabrics, woven sectors implying that these sectors have a 
comparative disadvantage (Table 8). The SITC 659 floor coverings tapestries and tablecloths sector is the most competitive sector in 2015. While the competitiveness of the SITC 652 cotton fabrics, woven, the SITC 657 special yarns, special textile fabrics and related products and the SITC 658 made-up articles, wholly or chiefly of textile materials sectors have declined, the competitiveness of the SITC 653 fabrics, woven, of man-made textile materials, the SITC 655 knitted or crocheted fabrics, the SITC 656 tulles, lace, embroidery, ribbons, trimmings and other small wares and the SITC 659 floor coverings tapestries and tablecloths sub-sectors have increased.

Table 8: The Vollrath's RTA Index for Turkish Textile Sector, 1989-2015

\begin{tabular}{cccccccccc}
\hline & 651 & 652 & 653 & 654 & 655 & 656 & 657 & 658 & 659 \\
\hline 1989 & 4,5 & 3,3 & 1,4 & 0,4 & 2,4 & 1,2 & 1,5 & 9,5 & 6,6 \\
\hline 1990 & 3,4 & 2,7 & 0,9 & 0,0 & 2,0 & 0,6 & 1,0 & 9,3 & 6,5 \\
\hline 1991 & 3,1 & 2,6 & 0,5 & 0,0 & 2,2 & 0,8 & 0,3 & 10,1 & 6,0 \\
\hline 1992 & 2,1 & 2,1 & 0,9 & 0,1 & 1,6 & 0,8 & 0,3 & 8,1 & 8,0 \\
\hline 1993 & 1,0 & 1,6 & 1,1 & 0,2 & 1,1 & 1,5 & 0,3 & 7,2 & 9,2 \\
\hline 1994 & 2,4 & 2,5 & 0,9 & 0,0 & 1,1 & 1,9 & $-0,3$ & 8,0 & 7,1 \\
\hline 1995 & 0,4 & 1,6 & 1,6 & 0,5 & 0,6 & 2,3 & $-0,1$ & 9,1 & 6,5 \\
\hline 1996 & 1,0 & 2,3 & 1,2 & 0,3 & 1,0 & 2,6 & 0,2 & 9,9 & 7,4 \\
\hline 1997 & 1,4 & 2,0 & 1,2 & $-0,3$ & 1,5 & 2,7 & 0,3 & 11,2 & 6,1 \\
\hline 1999 & 1,7 & 2,2 & 1,4 & $-0,3$ & 1,5 & 3,0 & $-0,3$ & 10,3 & 6,8 \\
\hline 2000 & 2,3 & 1,8 & 1,5 & $-0,1$ & 2,3 & 4,7 & $-0,5$ & 10,4 & 5,5 \\
\hline 2001 & 2,6 & 2,5 & 2,3 & 0,5 & 2,3 & 5,8 & 0,2 & 13,6 & 6,8 \\
\hline 2002 & 0,0 & $-0,1$ & 2,0 & $-0,7$ & 1,9 & 6,1 & $-0,2$ & 11,7 & 5,2 \\
\hline 2003 & $-0,3$ & $-0,2$ & 2,3 & $-0,9$ & 1,9 & 5,8 & $-0,2$ & 11,0 & 5,5 \\
\hline 2004 & 0,1 & 0,4 & 2,2 & $-1,4$ & 2,1 & 6,1 & 0,1 & 9,8 & 6,0 \\
\hline 2005 & $-0,1$ & 0,5 & 2,8 & $-1,0$ & 3,1 & 5,8 & 0,1 & 8,6 & 6,9 \\
\hline 2006 & 0,1 & 0,7 & 3,1 & $-0,9$ & 3,9 & 4,3 & 0,0 & 7,7 & 7,1 \\
\hline 2007 & $-1,5$ & 1,5 & 2,9 & $-0,6$ & 4,4 & 3,8 & 0,2 & 7,0 & 8,2 \\
\hline 2008 & $-0,8$ & 1,7 & 3,2 & $-0,5$ & 4,5 & 3,3 & 0,0 & 5,8 & 8,7 \\
\hline 2009 & $-1,1$ & 1,0 & 2,4 & $-0,8$ & 4,2 & 2,5 & $-0,2$ & 4,9 & 9,9 \\
\hline 2010 & $-1,3$ & 0,8 & 2,4 & $-0,7$ & 4,9 & 2,5 & 0,1 & 5,2 & 10,8 \\
\hline 2011 & $-0,3$ & 1,3 & 2,4 & $-0,6$ & 4,6 & 2,9 & 0,5 & 5,3 & 12,7 \\
\hline 2012 & $-1,0$ & 1,6 & 2,2 & $-0,9$ & 4,9 & 2,8 & 0,6 & 4,3 & 15,2 \\
\hline 2013 & $-0,4$ & 1,8 & 2,7 & $-0,7$ & 5,0 & 2,8 & 0,7 & 4,6 & 16,1 \\
\hline 2014 & $-1,0$ & 1,8 & 2,4 & $-0,9$ & 4,5 & 2,2 & 0,6 & 4,1 & 16,1 \\
\hline 2015 & $-0,9$ & 1,1 & 1,7 & $-1,2$ & 3,1 & 1,6 & 0,5 & 3,6 & 14,4 \\
\hline
\end{tabular}

Source: Calculations based on UNCOMTRADE database 
For the sub-sectors of Turkey's clothing industry, the RTA index indicates that Turkey has a comparative advantage but this trend is in decline. The competitiveness of almost all sub-sectors of clothing sector, except for SITC 846 Clothing accessories, of textile fabrics, has declined. SITC 844 Women's or girls' apparel, knitted or crocheted, SITC 845 Articles of apparel and clothing accessories for babies, articles of apparel of textile and SITC-846 Clothing accessories, of textile fabrics sectors were the most competitive sub-sectors in 2015. (Table 9)

Table 9: The Vollrath's RTA Index for Turkish Clothing Sector, 1989-2015

\begin{tabular}{|c|c|c|c|c|c|c|c|}
\hline & 841 & 842 & 843 & 844 & 845 & 846 & 848 \\
\hline 1989 & 6,7 & 8,7 & 3,5 & 14,1 & 10,6 & 3,0 & 17,8 \\
\hline 1990 & 6,4 & 8,7 & 4,8 & 16,8 & 10,6 & 3,3 & 21,3 \\
\hline 1991 & 5,2 & 8,0 & 4,7 & 19,4 & 10,9 & 4,2 & 17,6 \\
\hline 1992 & 4,0 & 5,6 & 4,8 & 22,3 & 9,2 & 3,7 & 11,8 \\
\hline 1993 & 4,1 & 5,8 & 5,2 & 22,2 & 9,3 & 4,3 & 10,5 \\
\hline 1994 & 4,0 & 5,6 & 6,4 & 17,1 & 9,3 & 4,9 & 9,6 \\
\hline 1995 & 5,6 & 7,7 & 8,4 & 21,0 & 11,0 & 5,6 & 8,5 \\
\hline 1996 & 4,8 & 7,4 & 8,7 & 17,7 & 10,9 & 5,6 & 6,0 \\
\hline 1997 & 4,7 & 6,8 & 6,1 & 13,9 & 9,3 & 4,9 & 6,4 \\
\hline 1998 & 4,7 & 7,0 & 6,8 & 14,1 & 10,2 & 4,9 & 5,6 \\
\hline 1999 & 4,9 & 7,5 & 6,0 & 11,8 & 9,6 & 5,1 & 5,3 \\
\hline 2000 & 5,0 & 8,2 & 5,3 & 11,9 & 9,5 & 5,5 & 5,7 \\
\hline 2001 & 4,4 & 7,6 & 4,5 & 9,4 & 7,8 & 5,4 & 4,8 \\
\hline 2002 & 4,9 & 7,9 & 4,9 & 9,6 & 8,3 & 5,9 & 4,6 \\
\hline 2003 & 4,7 & 7,0 & 3,8 & 9,3 & 8,3 & 6,2 & 3,5 \\
\hline 2004 & 4,7 & 6,5 & 3,2 & 7,4 & 7,2 & 6,2 & 2,6 \\
\hline 2005 & 4,6 & 6,0 & 3,1 & 6,9 & 6,8 & 5,9 & 2,0 \\
\hline 2006 & 4,0 & 5,4 & 3,0 & 6,3 & 5,8 & 5,6 & 2,1 \\
\hline 2007 & 3,9 & 5,2 & 2,7 & 5,7 & 5,1 & 5,3 & 1,9 \\
\hline 2008 & 3,4 & 4,1 & 2,7 & 5,1 & 4,1 & 4,3 & 1,5 \\
\hline 2009 & 3,1 & 3,7 & 2,7 & 5,1 & 3,9 & 4,9 & 1,0 \\
\hline 2010 & 3,4 & 4,1 & 2,3 & 5,6 & 4,5 & 4,9 & 1,1 \\
\hline 2011 & 3,1 & 4,0 & 2,1 & 4,9 & 4,2 & 4,6 & 1,1 \\
\hline 2012 & 3,5 & 4,2 & 2,3 & 3,9 & 4,3 & 3,7 & 0,8 \\
\hline 2013 & 3,3 & 4,2 & 2,5 & 3,8 & 4,5 & 4,4 & 0,8 \\
\hline 2014 & 3,1 & 3,8 & 2,8 & 4,2 & 4,4 & 4,4 & 0,5 \\
\hline 2015 & 3,3 & 3,7 & 2,8 & 4,4 & 4,1 & 3,8 & 0,0 \\
\hline
\end{tabular}

Source: Calculations based on UNCOMTRADE database 


\section{Conclusion}

In this study, Turkey's competitiveness in textiles and clothing industry was examined using Balassa's RCA index and Vollrath's RXA, RTA and RC index. The empirical analysis was based on trade data of the sector (SITC Rev.3 2 and 3 digit level of aggregation) which is obtained from the UN COMTRADE database for the period of 1989 to 2015.

The main results of this study are summarised as follows:

1. The analysis based on Balassa's RCA index shows that Turkey has a comparative advantage in both textile and clothing. Vollrath's RXA, RTA and RC indices also reveal that Turkey has a comparative advantage in textiles and clothing.

2. The competitiveness of the Turkish textile and clothing is high, although there has been a considerable decline in the competitiveness of clothing industry both as an aggregate commodity group and in the sub-sectors. Both Balassa's RCA and Vollrath's RTA index shows that the competitiveness of sub-sectors of clothing sector, except for SITC 846 Clothing accessories, of textile fabrics, has declined.

3. The decline in the SITC 848 Articles of apparel and clothing accessories of other than textile fabrics; headgear of all materials sector is remarkable. Balassa's RCA index indicates that the sector, which is the most competitive sector in 1989, has revealed comparative disadvantage in 2015.

4. The Balassa's RCA index shows that the textile sector is more competitive than the clothing sector in the world markets from 2008 to 2015 . The RCA index reveals that the competitiveness of most of the sub-sectors in textile sector has increased.

5. Vollrath's RTA index finds that the textile yarn (SITC 651) and other textile fabrics, woven sectors (SITC 654) has a comparative disadvantage since 2007.

Considering the contribution of the textile and clothing industry to the Turkish economy, maintaining and increasing the competitiveness of the sector is of vital importance for Turkey. In order to maintain and to increase the competitiveness of the sector it is necessary to focus on the production of high value-added goods and to develop a policy which its main aim is to create global brands and the policies should be developed to strengthen the sector's research and development capacity.

\section{References}

Balassa, B. (1965). Trade liberalization and revealed comparative advantage. The Manchester School of Economic and Social Studies, 33(2),99-123.

Çakmak, Ö.A. (2005). Açıklanmış karşılaştırmalı üstünlükler ve rekabet gücü: Türkiye tekstil ve hazır giyim endüstrisi üzerine bir uygulama. Ege Akademik Bakış, 5(1), 65-76.

Erkan, B. (2013). Türkiye'nin tekstil ve hazır giyim sektörü ihracatında uluslararası rekabet gücünün belirlenmesi. Anadolu Üniversitesi Sosyal Bilimler Dergisi, 13(1), 93-110. 
Gacaner Atış,A. (2014). Türkiye'nin tekstil ve konfeksiyon sektörünün karşılaştırmalı rekabet analizi. Ege Akademik Bakış, 14(2), 315-334.

Havrila, I. \& Gunawardana, P. (2003). Analysing comparative advantage and competitiveness: An application to Australia's textile and clothing industries. Australian Economic Papers, 42(1), 103-117.

Karaalp, H.S. \& Y1lmaz, N.D. (2012). An assessment of trends in comparative advantage and competitiveness of Turkish textile and clothing industries in the enlarged EU market. Fibres \& Textiles of Eastern Europe, 20,3(92), 8-11.

Karaalp, H.S. \& Yilmaz, N.D. (2013). Comparative advantage of textiles and clothing: Evidence for Bangladesh, China, Germany and Turkey. Fibres \& Textiles of Eastern Europe, 21,1(97), 14-17.

Kök, R. \& Çoban, O. (2015). Türkiye tekstil endüstrisi ve rekabet gücü: AB ülkeleriyle karşılaştırmalı bir analiz örneği, 1989-2001. Íktisat, İsletme ve Finans, 20(228),68-81.

Kösekahyaoğlu, L. \& Özdamar, G.(2009). Avrupa Birliği’ne üyelik sürecinde Türk imalat sanayinin rekabet gücündeki değişmeler. Süleyman Demirel Üniversitesi İktisadi ve İdari Bilimler Fakültesi Dergisi,14(1),17 - 30.

Liesner, H.H. (1958). The European common market and British industry. Economic Journal, 68(270), 302-316.

Turkish Statistical Institute (2016), Annual Industry and Service Statistics, http://tuik.gov.tr/ PreHaberBultenleri.do?id=21528, Erişim Tarihi: 29.12.2016.

Türkiye Tekstil ve Sanayi İşverenleri Sendikası (2015). Tekstil ve hazır giyim sanayinin Türk ekonomisindeki yeri. İstanbul: Türkiye Tekstil ve Sanayi İşverenleri Sendikası Yayını.

UN Comtrade Database (2016), Trade Statistics, http://comtrade.un.org/data/, Erişim Tarihi: 19.10.2016

Vollrath, T. L. (1991). A theoretical evaluation of alternative trade intensity measures of revealed comparative advantage. Weltwirtschaftliches Archiv, 130, 265-279.

Yılmaz, Ş. E. (2010). Dış ticaret kuramlarının evrimi. Ankara: Efil Yayınevi. 